$\begin{gathered}\text { Ana Dili Eğitimi Dergisi } \\ \text { Journal of Mother Tongue Education } \\ \text { www.anadiliegitimi.com }\end{gathered}$
Geliş/Received: 20.07 .2017 Kabul/Accepted:28.09.2017

\title{
Suriyeli Öğrencilere Türkçe Öğretmek için Kullanılan Ders Kitaplarının Öğretmen Görüşleri Doğrultusunda Değerlendirilmesi*
}

\author{
Nurşat BiÇER ${ }^{* *}$ \\ Bekir Sıttık KILIÇ
}

\begin{abstract}
Öz
Bu çalışmada Suriyeli öğrencilere Türkçe öğreten öğretmenlerin kullandığı Türkçe ders kitaplarına ilişkin görüşlerinin alınması amaçlanmışıı. Araştırma "Suriyeli Öğrencilerin Türk Eğitim Sistemine Entegrasyonu Projesi" kapsamında görev yapan 30 öğretmenle yürütülmüştür. Nitel desene göre tasarlanan çalışmanın verileri araştırmacılar tarafından hazırlanan yarı-yapılandırılmış görüşme formuyla elde edilmiştir. Söz konusu form Türkçe öğretimi alanında görev yapan bir okutman ve iki öğretim üyesinden uzman görüşü alınarak tekrar düzenlenmiştir. Daha sonra öğretmenler tarafından doldurulan görüşme formu üzerinde kodlama yapılarak veriler içerik analizine tabi tutulmuştur. Öğretmenlerden alınan görüşler ve önerilerden hareketle, yabancılara Türkçe öğretmek amacıyla hazırlanan ders kitaplarının içeriği, biçimsel özellikleri, öğrenci seviyesine uygunluğu, temel dil becerilerinin dağılımı ve etkinliklerin uygulanması hususunda düşünceler ortaya konmuştur. Sonuç olarak, öğretmenler ders kitabının farklı yönlerden birçok eksiğinin bulunduğunu belirtmişlerdir. Bununla beraber kitapların öğrenci seviyesine uygun olmadığı yönündeki düşünceleri öne çıkmaktadır.
\end{abstract}

Anahtar kelimeler: Yabancılara Türkçe öğretimi, Türkçe ders kitabı, Suriyeli öğrenciler, entegrasyon, nitel araştırma

\section{Evaluation of Text Books which are Used for Teaching Turkish to Syrian Students based on Teacher Opinions}

\begin{abstract}
The aim of this study is to obtain the opinions of teachers who teach Turkish to Syrian students about the Turkish text books they use. The research was conducted with 30 teachers who participated in the "Integration of Syrian Students into the Turkish Education System Project." The data for this study, which was designed as a qualitative endeavor, were collected using the semi-structured interview form prepared by the researchers. The interview form was revised after obtaining feedback from a lecturer and two faculty members who worked in the field of teaching Turkish. Afterwards, the data in the interview form filled out by teachers were coded and subject to content analysis. Based on the opinions and suggestions obtained from teachers, ideas were put forward with regard to the content, formal characteristics, compatibility with the student's level, distribution of basic language skills, and implementation of the activities in the text books which were prepared to teach Turkish to foreigners. Consequently, the teachers stated that the text books had a lot of deficiencies in different areas. Of those, teachers' opinion
\end{abstract}

\footnotetext{
* Bu çalışma 19-21 Mayıs 2017 tarihli 3. Uluslararası Yabancı Dil Olarak Türkçe Öğretimi Kongresi'nde sunulan bildirinin düzenlenmiş hâlidir.

** Yrd. Doç. Dr., Kilis 7 Aralık Üniversitesi, M. R. Eğitim Fakültesi, Türkçe Eğitimi ABD, nursatbicer@gmail.com.

${ }^{* * *}$ Arş. Gör., Kilis 7 Aralık Üniversitesi, M. R. Eğitim Fakültesi, Türkçe Eğitimi ABD, bskilic@kilis.edu.tr.
} 
that textbooks were not compatible with the level of the students was the one that stood out the most.

Keywords: Teaching Turkish to foreign students, Turkish text book, Syrian students, integration, qualitative research

\section{Giriş}

Yabancılara Türkçe öğretiminde öğrenmeyi sağlamak ve kalıcı hâle getirmek için çeşitli materyaller kullanılmaktadır. Bu materyaller arasında ders kitapları, çalışma kitapları, alıştırma kitapları, okuma kitapları gibi basılı materyaller yanında bilgisayar destekli görsel-işitsel uygulamalar da kullanılmaktadır. Bütün eğitim alanlarında olduğu gibi yabancı dil olarak Türkçe öğretiminde de ders kitapları en önemli ve en çok kullanılan materyallerden biridir. Çeşitli kurumlar tarafından hazırlanan Türkçe öğretimi ders kitapları genel kitlelere hitap edebileceği gibi tamamlayıcı öğretim materyali olarak farklı hedef kitlelere de hitap edebilir (Çalık, 2001). Hedef kitlenin yaşı, konuştuğu ana dili gibi özellikleri çerçevesinde ders kitapları hazırlanabilir. Farklı özelliklerine rağmen ders kitapları Türkçe öğretimini etkili bir şekilde gerçekleştirmeye yardımcı olma amacını taşırlar.

Ders kitapları hazırlanırken bilgi ve beceriler ortak bir amaç çerçevesinde herkese açık hâle getirilir. Bu sayede eğitim kurumları toplumun bir ögesi hâline gelebilmektedir. Bununla beraber yürütülen eğitim faaliyetlerinin toplumun tamamına ulaşmasında hazırlanan ders kitaplarının rolü büyüktür (Çelik ve Gülcü, 2016). Öğretim sürecine destek olmak amacıyla hazırlanan ders kitapları bazı özelliklere sahip olmalıdır. Bu kitaplar öğrenci düzeyine uygun, açık ve anlaşılır bir dille yazılmış olmalı; araştırmalar, hazırlık ve uygulama soruları içermeli; farklı öğretme ve öğrenme yaklaşımlarından yararlanmalı; çeşitli görsel uyarıcılarla zenginleştirilmiş olmalı; somut örnekler içermelidir (Komisyon, 2009). Belirtilen bu ögeler, ders kitabının kullanışlılığının ve süreci destekleme gücünün belirlenmesinde önem taşırlar. Duman'a (2013) göre ders materyallerinde; anlamlılık, bilinenden başlama, çok örnek, görelik, seçicilik, tamamlama, fonun anlamlılı̆̆ı, kapalılık, birleştiricilik, algıda değişmezlik, derinlik, yenilik, basitlik, hedef-davranış, öğrenciye uygunluk gibi ilkelere dikkat edilmesi gerekir.

Çağdaş ve geleneksel eğitim sistemleri içerisinde öğretmen ve öğrencilerin öğretim etkinliklerine aktif katılımları ve üretken olmaları, ders kitaplarının bünyelerinde barındırdı̆ı̆ niteliklere bağlıdır. Ders kitapları, tasarım, içerik, dil, öğreticilik, anlaşılabilirlik, estetik ve kullanılabilirlik gibi yönlerden okuyucunun seviyesine ve diğer eğitim teknolojilerinin kullanımına uygun hazırlanmalıdır (Tosunoğlu, Arslan ve Karakuş, 2001). Öğrencilerin hedeflenen dil becerilerini kazanmalarında; ders kitaplarının ulaşılabilir olması, yaygın bir şekilde kullanılması, tema ve konulara uygun metinlerden oluşması, öğrenci seviyesine uygun olması, doğru görsellerden oluşması, öğrenci çalışma kitabıyla uyumlu olması ve ölçme-değerlendirmenin (Göçer, 2007) yapııması başarılı 
Suriyeli Öğrencilere Türkçe Öğretmek için Kullanılan Ders Kitaplarının Öğretmen Görüşleri Doğrultusunda Değerlendirilmesi

sonuçların ortaya çıkmasına katkıda bulunur. Bir dili yabancılara öğretirken kullanılacak ders kitaplarının hazırlık ve incelenmesi için aşağıdaki unsurlar dikkate alınmalıdır:

- Materyallerin Hedef Kitlesi

- Hazırlanacak Materyallerde Uyulması Gereken IIlkeler

- Materyallerin Tanımlanması

- Genel Çerçeve

- Şekil Özellikleri

- Kültür Özellikleri

- Dil ve Anlatımı

- Dil Bilgisi Öğretimi (Demir, 2015).

Ders kitaplarının biçim ve içerik özellikleriyle öğrencilerin ilgisini çekmesi ve hedeflenen kazanımlara yöneltilmesinde, bilgiye ulaşmalarına ortam hazırlamada ve öğretimi bireyselleştirmede önemli işlevlere sahiptir (Göçer, 2007).

Ders kitapları yetişkinlerin yabancı dil olarak Türkçe öğretim sürecinde yaygın bir şekilde kullanılırken Suriyelilerin Türkiye'ye gelmesinden sonra birçok yaş düzeyini kapsayan bir sürece dönüşmüştür. Günümüzde Suriyelilerden her yaş düzeyinden insan Türkçeyi öğrenmeye çalışmaktadır. Yetişkinlerin eğitiminde İstanbul, Yeni Hitit, Yedi İklim ve Gazi Tömer kitapları kullanılırken çocuklar için temel materyal Türkçe Öğreniyorum adlı kitap setidir.

Yunus Emre Enstitüsü tarafından hazırlanan "Türkçe Öğreniyorum" seti ders kitabı, çalışma kitabı, dinleme kitapçığı ve ses CD’lerinden oluşmaktadır. Seriyi oluşturan 4 kitaptan her biri orta öğretim 1 - 4. sınıflarda okutulmak üzere tasarlanmıştır. Kitaplar A1 ve A2 düzeylerinin kazanımlarını kapsamaktadır. "Türkçe Öğreniyorum" seti 11-15 yaş arası kişilere yönelik düzenlenen kurslarda kullanılmak üzere hazırlanmıştır. Diğer ülkeler ve Türkiye'ye ait kültürel unsurlara değinilerek hazırlanan "Türkçe Öğreniyorum" seti ihtiyaç doğrultusunda yönergeleri Arapçaya tercüme edilmiştir. Suriyeli çocuklar için çeşitli dil öğretim ortamlarında kullanımlarına sunulmuştur (yee.org.tr).

Yabancı dil olarak Türkçe öğretiminde kullanılan ders kitaplarıyla ilgili çok sayıda çalışmanın yapıldığı söylenebilir. Göçer (2007) ders kitaplarını ölçme ve değerlendirme açısından ele almıştır. Özdemir (2013) ders kitaplarının işlevsel özelliklerine dikkat çeken bir çalışma yapmıştır. Gün, Akkaya ve Kara (2014) ders kitaplarının öğretim elemanları açısından değerlendirmesini yapmışlardır. Demir (2015) ders kitaplarının sahip olması gereken niteliklerle ilgili bir araştırma yapmıştır. Yavuz Kırık (2015) ders kitaplarındaki konuşma aktivitelerini incelemiştir. Kılınç ve Yenen (2015) ise yabancılara 
Türkçe öğretiminde kullanılan ders kitaplarının öğretim elemanlarının görüşlerine göre değerlendirmesini yapmışlardır.

Bu kitaplar kullanılırken öğretmenlerin bu kitaplara ilişkin görüşlerinin alınması da önem arz etmektedir. Suriyeli Çocukların Türk Eğitim Sistemine Entegrasyonu Projesi kapsamında ilkokul, ortaokul ve lise düzeylerinde kullanılan bu kitabın etkililiğinin belirlenmesi üzerine akademik çalışmaların yetersiz olması ve bu alana katkı sunma ihtiyacı bu çalışmanın yapılmasını sağlamıştır.

$\mathrm{Bu}$ çalışmada Suriyeli öğrencilere Türkçe öğreten öğretmenlerin kullandığı Türkçe Öğreniyorum adlı öğretim setine ilişkin görüşlerinin alınması amaçlanmıştır. Bu kapsamda aşağıdaki araştırma sorularına yanıt aranmıştır:

- Ders kitaplarının içeriğine yönelik öğretmenlerin görüşleri nelerdir?

- Ders kitaplarının biçimine yönelik öğretmenlerin görüşleri nelerdir?

- Ders kitaplarındaki temel dil becerilerine yönelik öğretmenlerin görüşleri nelerdir?

- Ders kitaplarının öğrenci seviyesine uygunluğuna yönelik öğretmenlerin görüşleri nelerdir?

- Ders kitaplarındaki etkinliklerin uygulanma süresine yönelik öğretmenlerin görüşleri nelerdir?

- Ders kitaplarında aranan niteliklere yönelik öğretmenlerin görüşleri nelerdir?

\section{Yöntem}

\section{Araştırmanın Modeli}

Betimsel modelde yapılan bu çalışmada nitel araştırma deseni kullanılmıştır. Nitel araştırma; gözlem, görüşme ve doküman analizi gibi veri toplama yöntemlerini kullanarak olgu ve olayları gerçekçi ve bütüncül bir biçimde ortaya koyan bir araştırma türüdür (Yıldırım ve Şimşek, 2008).

\section{Çalışma Grubu}

Araştırma, "Suriyeli Öğrencilerin Türk Eğitim Sistemine Entegrasyonu Projesi" kapsamında Kilis, Gaziantep ve Hatay'da görev yapan ve Türkçe Öğreniyorum setini kullanan öğretmenlerle yürütülmüştür. Türk Dili ve Edebiyatı, Türkçe ve Sınıf öğretmeni olarak görev yapan 30 öğretmen seçilerek görüşlerine başvurulmuştur. Tablo 1'de çalışma kapsamındaki öğretmenlerin özelliklerine ilişkin bilgi verilmiştir: 
Suriyeli Öğrencilere Türkçe Öğretmek için Kullanılan Ders Kitaplarıın Öğretmen Görüşleri Doğrultusunda Değerlendirilmesi

Tablo 1. Çalışma Grubunun Özellikleri

\begin{tabular}{llll}
\hline & & $\mathbf{( f )}$ & $\mathbf{N}$ \\
\hline Görev & Kilis & 14 & 30 \\
Yaptıkları & Hatay & 5 & \\
iller & Gaziantep & 6 & 30 \\
\hline Görev & İl Merkezi & 18 & \\
Yaptıkları & İlçe Merkezi & 5 & 30 \\
Yerler & Konteynır/Çadırkent & 7 & \\
\hline Görev & Illkokul & 14 & 30 \\
Yaptıkları & Ortaokul & 8 & \\
Okul & Lise & 2 & \\
Düzeyleri & Geçici Eğitim Merkezi & 6 & \\
\hline Mezun & Türkçe Öğretmenliği & 15 & \\
Oldukları & Sınıf Öğretmenliği & 7 & 8 \\
Bölümler & Türk Dili ve Edebiyatı & 8 & \\
\hline
\end{tabular}

Verilerin Toplanması

Çalışmada Suriyeli öğrencilere Türkçe öğreten öğretmenlerin kullandıkları Türkçe Öğreniyorum setleriyle ilgili görüşlerini almak için görüşme formu hazırlanmıştır. Görüşme sayesinde görüşülenlerin anlam dünyaları, duygu ve düşünceleri anlaşılarak ve daha derin bilgi edinilir (Kuş, 2012). Görüşme formları hazırlanırken Türkçe eğitimi alanında uzman olan 2 öğretim üyesinden ve 1 okutmandan görüş alınmıştır. Uzman görüşleri doğrultusunda formlarda gerekli düzenlemeler yapılmıştır. Son şekli verilen görüşme formları katılımcılara yazılı olarak uygulanmıştır. Araştırmacı tarafından katılımcıların isimlerinin ve bilgilerinin kimseyle paylaşılmayacağı kendilerine bildirilmiştir.

\section{Verilerin Analizi}

Öğretmenler tarafından doldurulan görüşme formu üzerinde kodlama yapılarak veriler içerik analizine tabi tutulmuştur. İçerik analizi elde edilen verilerin daha derinlemesine işlenmesini gerektirir (Yıldırım ve Şimşek, 2008). Çalışmada kodlama güvenirliğini sağlamak için araştırmacılar tarafından ayrı ayrı kodlamalar yapılmıştır. Kodlama sonucunda oluşturulan ortak kodlar ile ilgili daha detaylı açıklamalar yapmak için örnek ifadelere yer verilmiştir.

Araştırmacıların yaptığı kodlama süreci karşılaştırılarak verilerin güvenirliği hesaplanmıştır. Bu hesaplama için Miles ve Huberman'ın (1994) “Görüş Birliği / (Görüş Birliği + Görüş Ayrıllğı) x 100” formülü kullanılmıştır. Araştırmacılar arasındaki güvenirlik bu formül ,86 bulunmuştur. Uyum yüzdesinin ,70 veya daha üstü olması güvenilirlik için önemli görüldüğünden (Miles ve Huberman, 1994) analizin güvenilir olduğu düşünülmektedir. Bulgular, tablolar şeklinde sunulmuş ve kodlarla ilgili örnek katılımcı ifadelerine yer verilmiştir.

\section{Bulgular ve Yorum}

Suriyeli öğrencilere Türkçe öğretmek için kullanılan ders kitapları hakkında öğretmen görüşlerini inceleyen çalışmanın bulguları, kitapların içerik özellikleri, biçimsel özellikleri, kitaplarda 
temel dil becerilerinin dağılımı, kitapların öğrenci seviyesine uygunluğu, kitaplardaki etkinliklerin uygulanma süresi ve kitaplarda aranan nitelikler olmak üzere ayrı başlıklar altında sıralanmıştır. Kullanılan kitapların içeriğine ilişkin öğretmenlerin görüşleri alınmış ve buna ilişkin bilgiler Tablo 2'de sunulmuştur:

Tablo 2. Kitapların Iç̧erik Özellikleri

\begin{tabular}{llr}
\hline & $f$ & $\%$ \\
\hline İçeriğin her seviyeye uygun olmaması & 9 & 25 \\
Etkinliklerin yetersiz olması & 5 & 14 \\
İçeriğin basit olması & 5 & 14 \\
Görsellerin içeriği yansıtmaması & 4 & 11 \\
Türkçe öğretimi için uygun olması & 3 & 8 \\
Alfabe öğretimi için yetersiz olması & 3 & 8 \\
Türk kültürünü yansıtmaması & 2 & 5,5 \\
Diyalog metinlerinin yetersiz olması & 2 & 5,5 \\
Okuma metinlerinin yetersiz olması & 1 & 3 \\
Test mantığı ile hazırlanması & 1 & 3 \\
Günlük hayatla ilişkisinin zayıf olması & 1 & 3 \\
\hline \multicolumn{1}{c}{ TOPLAM } & 36 & $\mathbf{1 0 0}$
\end{tabular}

Ders kitaplarının içeriğine ilişkin öğretmen görüşlerine Tablo 2'de yer verilmiştir. Tablo incelendiğinde ders kitaplarının içeriğinin her öğrenci seviyesine uygun olmaması görüşü katılımcıların büyük çoğunluğu tarafından düşünülmektedir. Kitaplarda etkinliklerin yetersiz içeriğin ise basit olduğu öne çıkan diğer öğretmen görüşleri arasındadır. Öğretmenler her kademedeki öğrenci için aynı ve tek kitabın kullanıldığını bunun da öğretimde zorluklara sebep olduğunu ifade etmişlerdir. Öğretmenlere göre ders kitaplarındaki görseller içeriği yansıtmamaktadır. Söz konusu kitapların alfabe öğretimi için yetersiz olduğunu düşünen öğretmenlerle Türkçe öğretimi için uygun olduğunu düşünen öğretmen sayısının eşit olması Tablo 2'den çıkarılabilecek farklı bir durumdur. Kitapların Türk kültürünü yansıtmadığı ve günlük hayatla ilişkilendirilmesi konusunda yetersiz olduğu görüşü az da olsa öğretmen görüşleri arasında yer bulmaktadır. Ders kitaplarının içeriğinin her seviye(yaş) için uygun olmadığını belirten öğretmenlerden birinin ifadesine aşağıda yer verilmiştir:

K9: Kullandığım ders kitabı başlangıç noktasında uygun ama sonrasında çok kullanışlı değil çünkü çocukların Türkçe seviyeleri yok denecek kadar az ve boşluk doldurma eşleştirme tarzı etkinlikler var. Bunları çocuklara ifade edebilmek için biraz da olsa Türkçe konuşup anlamaları gerekiyor.

Kitaplardaki etkinliklerin yetersiz olduğunu ifade eden öğretmen görüşlerinden biri şöyledir:

K17: Yunus Emre Enstitüsü Türkçe Öğreniyorum setini kullanıyorum. Yaş grubunu da göz önünde bulundurarak A1 seviyesi için kitap içeriğini uygun ancak metin ve etkinlik açısından yetersiz buluyorum. 
Suriyeli Öğrencilere Türkçe Öğretmek için Kullanılan Ders Kitaplarının Öğretmen Görüşleri Doğrultusunda Değerlendirilmesi

İçeriğin öğrenciler için basit olduğunu belirten 5 öğretmenden $1^{\prime} i$ görüşünü şu şekilde ifade etmiştir:

K11: Kitap içeriği basit düzeyde ele alınmış. Bizim Türkçe öğreteceğimiz Suriyeli çocukların seviyeleri göz önüne alınmamış.

Kullanılan kitapların biçimsel özelliklerine ilişkin öğretmenlerin görüşleri alınmış ve buna ilişkin bilgiler Tablo 3'te sunulmuştur:

Tablo 3. Kitapların Biçimsel Özellikleri

\begin{tabular}{lll}
\hline & $f$ & $\%$ \\
\hline Biçim olarak güzel ve uygundur & 10 & 28 \\
Sade ve basit anlatımın kullanılması & 6 & 17 \\
Görseller açıından zengin olması & 5 & 14 \\
Baskı kalitesinin düşük olması & 4 & 11 \\
Görsellerin renklerinin cansızlığı & 4 & 11 \\
Yazım hatalarının olması & 4 & 11 \\
Renk ve boyutun uygun olması & 2 & 5 \\
Yazı boyutunun küçük olması & 1 & 3 \\
\hline TOPLAM & 36 & $\mathbf{1 0 0}$ \\
\hline
\end{tabular}

Tablo 3 öğretmenlerin, Suriyeli öğrencilere Türkçe öğretmek amacıyla derslerde kullandıkları kitapların biçimsel özelliklerine dair görüşlerini göstermektedir. Tabloya göre öğretmenlerin çoğunluğu kitapların biçimsel olarak güzel ve uygun olduğunu ifade etmektedir. Kitaplarda anlatımın sade ve basit bir üslup kullanıldığı görüşünde olan öğretmenler ikinci sırada yer almaktadır. 5 öğretmen kitapların görseller açıdan zengin olduğunu düşünürken; 5 öğretmen baskı kalitesinin düşük, 4 öğretmen de görsellerdeki renklerin cansız ve mat olduğunu düşünmektedir. Görüş bildiren öğretmenler arasından 1 kişi de yazı boyutunun küçük olduğunu ifade etmiştir. Kitapların güzel ve uygun olduğunu belirten bir öğretmen görüşü şöyledir:

K3: Kitaplar biçimsel, renk ve boyut olarak uygun olarak hazırlanmıştır denilebilir. Kolay taşınabilir renkli ve eğlenceli çalışmaları bulunuyor.

Biçimsel özelliklerin uygun ve güzel olduğunu düşünen bazı öğretmenler kitaplarda yazım yanlışlarının bulunduğunu ve baskı kalitesinin iyileştirilebileceğini ifade etmektedirler. Bu şekilde düşünen 2 öğretmenin görüşleri şöyledir:

K18: Biçimsel özellikleri güzel ancak yazım hataları var.

K20: Biçim bağlamında kitaplar öğrenciyi sıkmayacak ve yormayacak boyutta. Baskı ve görsellik bağlamında daha kaliteli bir basım yapılabilir.

Kitaplarda kullanılan görsellerde kullanılan renk ve tonlamalarda sıkıntılar olduğunu ifade eden 4 öğretmenden 1'i görüşünü şu şekilde dile getirmektedir: 
K15: Biçim olarak incelendiği zaman kitapta yer alan bazı resimleri, hayal dünyasını çocuklara daha yakın tutan bir sınıf öğretmeni olarak ben bile anlamakta zorluk çektim. Biz bu zorluğu yaşayıp bir an olsa bile bocalayarak çelişkiye düşüyorsak bir çocuktan daha iyi yapmasını nasıl bekleyebiliriz?

Kullanılan kitaplardaki temel dil becerilerinin dağılımına ilişkin öğretmenlerin görüşleri alınmış ve buna ilişkin bilgiler Tablo 4'te sunulmuştur:

Tablo 4. Kitaplardaki Temel Dil Becerilerinin Dağılımı

\begin{tabular}{lll}
\hline & $f$ & $\%$ \\
\hline Dinleme/izleme yetersiz & 13 & 30 \\
Konuşma yetersiz & 9 & 20 \\
Yazma yeterli & 9 & 20 \\
Dağılım eşit ve uygun şekildedir & 4 & 9 \\
Okuma yetersiz & 3 & 7 \\
Yazma yetersiz & 2 & 5 \\
Okuma yeterli & 3 & 7 \\
Gramer ağırlıklı hazırlanmıştır & 1 & 2 \\
\hline TOPLAM & $\mathbf{4 4}$ & $\mathbf{1 0 0}$ \\
\hline
\end{tabular}

Ders kitaplarında temel dil becerilerinin dağılımına ilişkin alınan görüşler tablo 4 'te gösterilmiştir. Öğretmenlerin genellikle dinleme/izleme becerisinin yetersiz olduğu görüşünde oldukları ve tabloda ilk sırada yer aldıkları görülmektedir. Öğretmenler ayrıca dinleme/izleme becerisinin önemli bir beceri olmasına rağmen ihmal edildiği bunun da kitaplara yansıdığını ifade etmektedirler. Konuşma dil becerisine de gereği kadar yer verilmediğini düşünen 9 öğretmen bulunmaktadır. Yazma becerisini 9 öğretmen yeterli görürken 2 öğretmen bu konuda tam tersini düşünmekte yani yazma becerisinin kitaplarda yetersiz kaldığını düşünmektedir. Görüş bildiren 4 öğretmen dağılımın gerektiği kadar yapılıp becerilerin eşit miktarda yer aldığını düşünmektedir. Kitapların gramer ağılıklı hazırlandığını düşünen tek öğretmen görüşü de tabloda görülmektedir. Kitaplarda dinleme/izleme becerisin yetersiz olduğunu düşünen bir öğretmenin görüşü şöyledir:

K21: Temel dil becerileri açısından okuma ve yazmaya uygun etkinlikler içermekte fakat dinleme açısından fazla bir etkisi yoktur.

Konuşma becerisine yeteri kadar yer verilmediğini düşünen 9 öğretmenden birinin görüşü şu şekildedir:

K19: Dil becerilerinin dağılımı noktasında da önemli eksiklikler var. Dinleme ve konuşma etkinliklerine yeteri kadar yer verilmemiştir. Kitabın içeriğini yazma etkinlikleri oluşturuyor. Diğer etkinlikler de yazma etkinliklerini destekler nitelikte.

Yazma dil becerisine yeteri kadar verildiğini düşünen 9 öğretmenden 1'inin görüşü şu şekildedir: 
Suriyeli Öğrencilere Türkçe Öğretmek için Kullanılan Ders Kitaplarının Öğretmen Görüşleri Doğrultusunda Değerlendirilmesi

K1: Genel olarak yazma dil becerisi ağırlıktadır. Bu şekilde düşünenlerin yanı sıra yazma ve okuma becerilerinin yetersiz olduğunu düşünen katılımcılar da mevcuttur.

Kitaplarda temel dil becerilerinin dağılımının eşit ve uygun olduğunu ifade eden bir öğretmenin görüşü ise şöyledir:

K24: Dağııımın gerektiği miktarda yapıldığını düşünüyorum.

Kullanılan kitapların öğrenci seviyesine uygunluğuna ilişkin öğretmenlerin görüşleri alınmış ve buna ilişkin bilgiler Tablo 5'te sunulmuştur:

Tablo 5. Kitapların Öğrenci Seviyesine Uygunluğu

\begin{tabular}{llc}
\hline & $f$ & $\%$ \\
\hline Her (yaş) seviye için uygun değildir & 17 & 59 \\
Öğrenci seviyesine uygundur & 4 & 14 \\
İlkokullar için uygun değildir & 3 & 10 \\
İlkokullar için uygundur & 3 & 10 \\
Ortaokul ve lise için uygundur & 2 & 7 \\
\hline TOPLAM & $\mathbf{2 9}$ & $\mathbf{1 0 0}$ \\
\hline
\end{tabular}

Tablo 5'te Suriyeli öğrencilere Türkçe öğretiminde kullanılan kitapların öğrenci seviyesine ne derece uygun olduğuna dair görüşlere yer verilmiştir. 17 öğretmen söz konusu kitapların her seviyeye (yaşa) uygun olmadığı, kitapların ayrım yapmaksızın hazırlandığı görüşünü bildirmektedirler. Bu konuda görüş belirten diğer öğretmenlerin görüşleri derlendiğinde; 4'ü kitapların öğrenci seviyesine uygun olduğunu, 3'ü ilkokullar için uygun olmadığını belirtirken 3'ü ilkokullar için uygun olduğunu, 2'si ise ortaokul ve liseler için daha uygun olduğunu belirtmişlerdir. Değişik okul kademelerinde aynı kitapların kullanılması bazı öğrencilerin öğrenmede güçlük çekmesine bazı öğrencilerin ise derslerde sıkılmalarına sebep olduğu düşünülmektedir. Kitapların ilkokul seviyesine uygun olduğunu düşünen katılımcı sayısıyla uygun olmadığını düşünen katılımcı sayısının eşit olduğu görülmekte bu konuda öğretmenler arasında görüş ayrılı̆ı̆ olduğu dikkat çeken bir husustur. Bu görüşlerden farklı olarak az da olsa derslerde kullanılan ders kitaplarının ortaokul ve lise için uygun olduğunu ifade eden katılımcılar mevcuttur. Kitapların öğrenci seviyesine uygun olmadığını düşünen öğretmenlerden 3’ünün görüşü şu şekildedir:

K18: 2. sınıftan 12. sınıfa kadar bütün öğrenciler tek bir kitap kullanıyor. Pedagojik olarak düşünüldüğünde puntoların, resimlerin ve anlatılan konuların veya konuların anlatış biçiminin yaş seviyesine uygun olması gerektiğini düşünüyorum.

K11: Öğrenci seviyesi göz önüne alınmamış çünkü ilkokul, ortaokul, lise seviyesindeki öğrencilere aynı kitap verildiği için ortaokul ve lise düzeyindeki öğrenciler sıkılmakta ve derse motive olamamaktadır.

K30: Bazı kitaplar çok basit düzeydeyken bazı kitaplar ise ağır bir düzeyde kalmaktadır. 
Kitapların öğrenci seviyesine uygun olduğunu düşünen 4 öğretmenden 1'inin görüşü şöyledir:

K21: Kitaplar öğrenci seviyesine uygundur. Illkokul öğrencileri genelde ilk kez Türkçeyle tanıştıkları için basit düzeyde oluşu öğrenciye görelik ilkesine uygundur.

Öğretmenlerin derslerde kullandıkları kitapların öğrenci seviyesine uygunluğu ile ilgili diğer öğretmen görüşleri de şunlardır:

K7: Kitaplar daha basit düzeyde ele alınmalı ve konuları işleyiş zamanı biraz daha uzun olmalıydı.

K30: Bazı kitaplar çok basit düzeydeyken bazı kitaplar ise ağır bir düzeyde kalmaktadır.

Kullanılan kitaplardaki etkinliklerin uygulanma süresine ilişkin öğretmenlerin görüşleri alınmış ve buna ilişkin bilgiler Tablo 6'da sunulmuştur:

Tablo 6. Kitaplardaki Etkinliklerin Uygulanma Süresi

\begin{tabular}{lll}
\hline & $f$ & $\%$ \\
\hline Uygulama süresi yeterlidir & 11 & 42 \\
Uygulama süresi yeterli değildir & 6 & 23 \\
Etkinlikler kısa sürmektedir & 3 & 11,5 \\
Etkinlik sayısı artırılabilir & 3 & 11,5 \\
Bazı ekinlikler uzun bazı etkinlikler kısa sürüyor Etkinlikler fazla zaman & 2 & 8 \\
alıyor & 1 & 4 \\
\hline TOPLAM & $\mathbf{2 6}$ & $\mathbf{1 0 0}$ \\
\hline
\end{tabular}

Tablo 6'da ders kitaplarındaki etkinliklerin uygulanma süreleri ile ilgili öğretmen görüşleri yer almaktadır. Ders kitaplarında yer alan etkinliklerin uygulanma süresiyle ilgili görüş bildiren 6 öğretmen etkinliklerin uygulanma süresini yetersiz, 3 öğretmen etkinliklerin kısa olduğunu düşünmektedir. Etkinlik sayısının artırabileceği, etkinliklerin bazılarının kısa bazılarının ise uzun sürdüğü diğer görüşlerdendir. Ayrıca etkinliklerin fazla zaman almadığı yalnız 1 öğretmen tarafından düşünülmektedir. Etkinlik sürelerinin yeterli olduğunu, yetersiz olduğu durumlarda bazı öğretmenler ek sürelerle bunu telafi ettiklerini, sürenin çok problem olmadığını ifade eden öğretmen görüşlerinden 2'si şöyledir:

K27: Etkinliklerin uygulama süreleri yeterli çok fazla uzun sürmüyor.

K13: Zamanın yeterli olduğu kanaatindeyim. Çünkü her öğrenciye kazanımı uygulama zamanımız oluyor. Yeterli olmayınca ek surelerle tamamlıyoruz. Sonuçta dil gelişimi tamamlanmış bireylerle de aynı ortamı paylasan hazır bulunuşluğu tam öğrenciler de bulunmakta.

Sürenin yeterli olmasına rağmen etkinliklerin konunun anlaşılma noktasında yetersiz kaldığını, etkinliklerin çoklu zekâ kuramına göre hazırlanmadığını ifade eden diğer bir katıımcı şu şekilde düşünmektedir: 
Suriyeli Öğrencilere Türkçe Öğretmek için Kullanılan Ders Kitaplarının Öğretmen Görüşleri Doğrultusunda Değerlendirilmesi

K2: Suriyeli mültecilere haftalık 15 saat Türkçe dersi anlatılmaktadır. Kitaptaki etkinlikler için süre yeterlidir. Ama kitaptaki etkinlikler konunun anlaşılması için yeterli değildir. Bütün etkinlikler kitaba ve yazıya dayanmaktadır. Bütün zekâ alanlarını kapsayan etkinlik örneklerinin kitapta yazılması daha faydalı olacaktır.

Etkinliklerin uygulanma süresinin yetersiz olduğunu düşünen öğretmenler etkinlik sürelerinin yetersiz olmasını kalabalık sınıflara, sınıflarda disiplinin sağlanamamasına ve sistemin tam olarak oturmamasına bağlamaktadırlar. Etkinliklerin yetersiz olduğunu düşünen 2 öğretmen görüşü ise şöyledir:

K25: Etkinliklerin uygulama süresi çok kısa. Bu nedenle akılda kalıcı olmuyor.

Etkinlik sürelerinin yeterli ve yetersiz olduğunu düşünenlerin yanı sıra kimi katılımcılar sürenin etkinliğe göre değişebildiğini, bazı etkinlikler kısa sürede yapııırken bazılarının uzun sürede gerçekleştirildiğini belirtmektedirler.

Kitaplarda aranan niteliklere ilişkin öğretmenlerin görüşleri alınmış ve buna ilişkin bilgiler Tablo 7'de sunulmuştur:

Tablo 7. Kitaplarda Aranan Nitelikler

\begin{tabular}{llc}
\hline & $f$ & $\%$ \\
\hline Öğrenci seviyesine uygun olmasını & 10 & 22 \\
Dil becerilerinin dengeli dağılımda olmasını & 7 & 16 \\
Etkinliklerin fazla olmasını & 5 & 11 \\
Kültürümüze ait unsurlara yer verilmesini & 4 & 9 \\
Sade ve açık olmasını & 3 & 7 \\
Görsellerin profesyonel olmasını & 3 & 7 \\
Bol örnek verilmesini & 3 & 7 \\
Görsellerin fazla olmasını & 2 & 4,4 \\
Günlük hayattan izler taşımasını & 2 & 4,4 \\
Baskı kalitesinin iyi olmasını & 2 & 4,4 \\
Grup ile yapılabilecek etkinliklere yer verilmesini & 1 & 2 \\
Farklı cümle yapılarına yer verilmesini & 1 & 2 \\
Yazım yanlışlarının olmamasını & 1 & 2 \\
Öğretmen kılavuz kitabı olmasını & 1 & 2 \\
\hline TOPLAM & 45 & 100 \\
\hline
\end{tabular}

Suriyeli öğrencilere Türkçe öğretmek amacıyla hazırlanan ders kitaplarının nasıl olması gerektiğine ilişkin alınan görüşler Tablo 7'de gösterilmiştir. 10 öğretmen kitapların öğrenci seviyesine uygun olmasını istediklerini söylemiş ve frekans sıklığı bakımından ilk sırada yer almışlardır. Kitabın içeriğine ilişkin görüşlere koşut olarak bu konuda da öğretmenlerin genellikle aynı görüşte olduklarını, Tablo 2'deki verilerle benzer özellikler gösterdiğini söylemek mümkündür. Tablodaki diğer görüşler derlendiğinde; 7 öğretmen kitaplarda temel dil becerilerinin dağılımının dengeli ve eşit olmasını, 5 öğretmen etkinlik sayılarının artırılmasını, 4 öğretmen kitaplarda Türk kültürüne ait unsurlara yer verilmesini istemektedir. Öğretmenler Türk kültürüne uygun olmayan yaşam şekillerinin, Türk 
kültürüne ait olmayan unsurların metinler arasında yer aldığını ifade etmektedirler. Kitapların açık ve sade bir dille yazılması, görsellerin daha profesyonel hazırlanması, örnek sayılarının artırılması, baskı kalitesinin iyi olması, görsellerin profesyoneller tarafından hazırlanması ve sayılarının artırılması, kitapta yazım yanlışlarının olmaması ve kitaplarda farklı cümle yapılarına yer verilmesi kitaplarda olması arzu edilen diğer özellikler arasında yer almaktadır. Kitapların her seviye veya yaşa uygun olmasını isteyen bir öğretmen görüşü şöyledir:

K22: Canlı ve bol örneklerle donatılmış olması ve her seviye ve öğrenci sınıflarına göre ayrı ayrı hazırlanmış olmasını isterdim.

Dil becerilerinin dağılımının dengesiz olduğunu ifade eden öğretmenlerden birinin görüşü şöyledir:

K4: Kullanacağım kitap her açıdan öğretimi destekleyecek bir içeriğe sahip olmasını, temel dil becerilerinin önemine uygun bir içerikle hazırlanmış ve etkinliklerin öğrenci açısından öğrenmeyi sağlayacak yönde zengin bir içerikle hazırlanmış olmasını isterdim.

Kitapların sade ve açık şekilde hazırlanmasını, bol örnekler içermesini ve sık tekrar yapılmasını isteyen katılımcılardan biri düşüncesini şöyle ifade etmektedir:

K1: Sade, açık ve tekrara dayalı olması gerekir dil öğretiyoruz tekrar çok önemli her ünite sonunda eski ünite den tekrar bahsetmek gerekir diyerek açıklamaktadır.

\section{Sonuc}

Suriyeli öğrencilere Türkçe öğretmek için öğretmenlerin derslerinde kullandıkları ders kitaplarına ilişkin bazı görüşler geliştirdikleri bilinmektedir. Bu çalışmada öğretmenlerin kullandıkları kitaplara yönelik geliştirdikleri görüşler altı başlık altında ele alınmıştır.

Ders kitaplarının içeriğine dair alınan görüşler çerçevesinde; ders kitaplarının öğrenci seviyesine uygun olmadığı, her seviye, yaş veya kademedeki farklı öğrenciler için tek kitap kullanıldığı görülmektedir. Ders kitaplarının içeriğinin Türkçe öğretmek için uygun olduğunu düşünen 3 öğretmen dışında bütün öğretmenler, kitapların içeriğinin çeşitli açılardan yetersiz ve olumsuz olduğu yönünde görüş bildirmektedirler. Çelik ve Gülcü'nün (2016) ders kitaplarının içeriğine ilişkin görüşleri aldığı çalışmasında kitapların günlük hayatla ilişkisi, etkinliklerin öğrenci seviyesine uygunluğu maddelerini hiçbir öğretmen yeterli bulmamış ve \%100 geliştirilmeli şeklinde görüş belirtmişlerdir. Türk kültürünün daha fazla yansıtılması gerektiği görüşü Kılınç ve Yenen (2015) tarafından da dile getirilmiştir. Demir'e (2015) göre yabancılara Türkçe öğretiminde kullanılacak ders kitaplarındaki metinlerin Türk kültürünün özelliklerini olumlu yönde ve en güzel biçimde yansıtabilmelidir. Çalışmanın sonucunun daha önce yapılan çalışmalarla benzer özellikler gösterdiği görülmektedir. 
Suriyeli Öğrencilere Türkçe Öğretmek için Kullanılan Ders Kitaplarının Öğretmen Görüşleri Doğrultusunda Değerlendirilmesi

Kitapların biçimsel özellikleri hakkında görüşleri alınan öğretmenler, kitapları biçimsel açıdan yeterli ve uygun bulmaktadırlar. Kitapların biçimsel özellikleri konusunda olumsuz görüş bildiren öğretmenler sebep olarak görsellerdeki renklerin cansız olmasını, yazım hatalarının bulunmasını, yazı boyutunun küçük olmasını göstermektedirler. Gün, Akkaya ve Kara'nın (2014) yapmış olduğu çalışmada, yabancılara Türkçe öğretimi için kullanılacak için seçilen kitaplarda görsel unsurların ve tasarımın uygunluğu aranan nitelikler arasında yer alması gerektiği ifade edilmiştir. Kılınç ve Yenen (2015) ise bazı kitaplardaki görsel içeriğin yetersiz kaldığı ve görsel içeriğin arttırılması şeklinde görüş belirtmişlerdir. Bu sonuçlara göre yabancılara Türkçe öğretimi alanındaki birçok kitapta biçimsel eksikliklerin olduğu söylenebilir.

Kitaplarda temel dil becerilerinin dağılımı konusunda dinleme/izleme dil becerisine gereği kadar yer verilmediği, söz konusu becerinin ihmal edildiği bunu konuşma becerisinin takip ettiği görülmektedir. Öğretmenlerin temel dil becerileri arasında yeterli olarak gördüğü beceri yazmadır. Kitapların gramer ağırlıklı yazıldığını düşünen öğretmenler de vardır. Bazı öğretmenler ise dağıımın dengeli ve yeterli olduğu görüşünü ifade ettikleri dikkat çekmektedir. Kılınç ve Yenen (2015) dinleme etkinliklerinin interaktif CD'lerle güçlendirilmesi ve konuşmayı teşvik edici etkinliklerin arttırılması gibi görüşlerin olduğunu belirtmişlerdir.

Ders kitaplarının öğrenci seviyesine uygunluğuna dair görüşler içerisinde, söz konusu kitapların öğrencilerin seviyelerine uygun olmadığı ağır basmaktadır. Aynı düşüncenin ders kitaplarının içeriğine dair görüşlerle koşut özellikler gösterdiği görülmektedir. Öğrenci seviyesine uygun olduğunu belirten öğretmenlerin yanı sıra kitapların belli kademedeki öğrenciler için daha uygun olduğu fikrinde olan öğretmenler de mevcuttur. Bu yargı ders kitaplarının her seviyeye uygun olmadığını destekler mahiyettedir.

Kitaplarda yer alan etkinliklerin uygulanma sürelerine ilişkin görüşlerin alındığı başlık altında öğretmenlerin genellikle süreyi yeterli buldukları görülmektedir. Ders süresi içinde yetişmeyen etkinlikler ek sürelerle telafi edilmekte, bu da öğretmenlerce ciddi bir problem olarak görülmemektedir. Etkinliklerin sürelerini yeterli bulmayan öğretmenler bu durumu; sınıfların kalabalık olmasına, disiplin sorunlarına bağlamakta, diğer bir ifadeyle etkinliklerin kendisinden kaynaklanan bir sorun olmadığını ifade etmektedirler. Etkinliklerin zaman aldığını söyleyen bir görüş bulunmaktadır.

Son başlık altında öğretmenlerin ders kitaplarında olmasını istedikleri özelliklere ilişkin görüşler yer almaktadır. Daha önceki başıklar altındaki görüşleriyle benzer olarak öğretmenler, kitapların öğrenci seviyesi göz önüne alınarak hazırlanması gerektiğini düşünmektedirler. Dil becerilerinin yeterli ve dengeli dağılması, kültürümüze ait motiflerin kitaplarda daha fazla yer alması, 
etkinlik sayısının artırılması, görsel kalitesinin iyileştirilmesi ve kitapların günlük hayatla daha çok ilişkilendirilmesi, öğretmenler tarafından istenen diğer niteliklerdendir. Her bireyin olduğu gibi Türkçe öğrenen yabancı öğrencilerin de farklı deneyimlere ve farklı algılama düzeylerine sahip oldukları bilinmektedir. Özdemir'e (2013) göre öğrencilerin sahip oldukları bu bireysel farklılıkların, sınıf içinde ya da dışında kendilerine yöneltilen bilgi girdilerini algılama miktarları üzerinde önemli ölçüde etkisi olmaktadır. Bu açıdan yabancılara Türkçe öğretiminde sık kullanılan ders kitaplarının içeriğinin, öğrencilerin bireysel farklılıkları esas alınarak, her öğrencinin seviyesine uygun şekilde hazırlanması önem arz etmektedir.

Öğretmenlerin Suriyeli öğrencilere Türkçe öğretmek için kullanmış oldukları ders kitaplarına yönelik genellikle olumsuz bir görüş içinde oldukları tespit edilmiştir. Ders kitaplarından etkin olarak yararlanmak, Türkçe öğretimini daha nitelikli yapmak belirlenen amaçlara ulaşmayı kolaylaştıracaktır. Yabancılara Türkçe öğretiminde en çok kullanılan materyallerden olan ders kitapları her açıdan sağlıklı ve nitelikli hazırlanarak öğrencilerin Türkçeyi daha iyi öğrenmelerine katkıda bulunulabilir. Bu sonuçlar çerçevesinde aşağıdaki öneriler sunulabilir:

- Ders kitapları içerik bakımından tekrar gözden geçirilerek özellikle içerik öğrencilerin yaşlarına ve devam ettikleri okul kademesine göre tekrar hazırlanabilir.

- Dil öğretiminde temel dil becerilerini birbirinden bağımsız düşünmek mümkün değildir. Bu nedenle ders kitaplarında bütün temel becerilerin dengeli şekilde yer alması sağlanabilir.

- Kitabın kapak tasarımından yazı puntosuna ve biçim özelliklerine kadar bütün unsurlarına dikkat edilip bu hususta profesyonel destek alınabilir. Bu şekilde ders kitapları görsel unsurlar bakımından öğretimi destekleyici ve öğrencinin daha çok ilgisi çekebilecek hâle getirilebilir.

- Öğretmenler için kılavuz kitap hazırlanıp, öğretmenlere bu konuda hizmet içi eğitimi verilebilir.

- Dil öğretimi aynı zamanda kültür öğretimidir. Ders kitaplarında ülkemizi doğru şekilde tanıtacak, Türkçe öğrenmelerini kolaylaştıracak kültürel motiflere, türkülere, şarkılara $v b$. gelenek ve göreneklere yer verilebilir.

- Bu çalışmada 30 öğretmenle çalışılmıştır. Büyük örneklemlerle çalışılabilmesi için, araştırmacılar teşvik edilebilir.

\section{Kaynaklar}

Çalık, T. (2001). Türkçe ders kitaplarının biçim ve tasarımı, konu alanı ders kitabı inceleme kılavuzu, Türkçe 1-8. Ankara: Nobel Yayın Dağıtımı.

Çelik, Y. ve Gülcü, i (2016). Yurtdışında kullanılan Türkçe ve Türk kültürü ders kitaplarına yönelik öğretmen görüşleri. Bartın Üniversitesi Eğitim Fakültesi Dergisi, Cilt 5, Sayı 2, s. 287 - 296. 
Suriyeli Öğrencilere Türkçe Öğretmek için Kullanılan Ders Kitaplarının Öğretmen Görüşleri Doğrultusunda Değerlendirilmesi

Demir, T. (2015). Yabancı dil olarak Türkçe öğretiminde materyal yetkinliği -ders kitapları-. Dil Dergisi, 166/1, 43-52.

Duman, G. B. (2013). Türkçenin yabancı dil olarak öğretiminde materyal geliştirme ve materyallerin etkin kullanımı. Ana Dili Eğitimi Dergisi, 1(2),1-8.

Göçer, A. (2007). Türkçenin yabancı dil olarak öğretiminde kullanılan ders kitaplarının ölçme ve değerlendirme açısından incelenmesi. Dil Dergisi, 137, 30-48.

Gün, M., Akkaya, A. ve Kara, Ö. T. (2014). Yabancılara Türkçe öğretimi ders kitaplarının Türkçe öğretim merkezlerinde görev yapan öğretim elemanları açısından değerlendirilmesi. Turkish Studies, 9/6, p. 1-16.

http://www.yee.org.tr/tr/turkceogretimsetleri

Kılınç, H. H. ve Yenen, E. T. (2015). Yabancılara Türkçe öğretiminde kullanılan ders kitaplarına ilişkin öğretim elemanlarının görüşleri. International Journal of Language Academy, 3/4, 429-441.

Komisyon. (2009). Öğretim yöntem ve teknikleri. Ankara: Ihtiyaç Yayınları.

Kuş, E. (2012). Nicel-nitel araştırma teknikleri. Ankara: Anı Yayıncılık.

Miles, M. B. \& Huberman, M. A. (1994). Qualitative data analysis. London: Sage Publication.

Özdemir, C. (2013). Yabancılara Türkçe öğretiminde ders malzemelerinin önemi ve işlevsel ders malzemelerinin nitelikleri. Turkish Studies, 8/1, p. 2049-2056.

Tosunoğlu, M., Arslan, M., Karakuş, . (2001). Konu alanı ders kitabı inceleme. Ankara: Anıttepe.

Yavuz Kırık, M. (2015). Interaction level of speakıng actıvitıes ın a coursebook serıes of teachıng turkısh as a foreign language. Hasan Ali Yücel Eğitim Fakültesi Dergisi, 12-2(24), s.133-145

Yıldırım, A. ve Şimşek, H. (2008). Sosyal bilimlerde nitel araştırma yöntemleri. (6. Baskı). Ankara: Seçkin Yayıncilık. 